\title{
THE ROLE OF HUMAN RESOURCE MANAGEMENT IN THE REVITALIZATION OF MORIBOND ENTERPRISE
}

\author{
Fanisi Temitope Babatunde \\ Doctoral Student \\ Department of Business \& Entreprenuership Studies \\ Afe Babalola University, Ado-Ekiti \\ Nigeria \\ E-MAIL: babatundephanisy@yahoo.com \\ $+2348067183075$
}

\begin{abstract}
Human resources management plays a significant role in the actualization of organizational goals. It provides the organisation with various strategies and design policies to sustain the organisation. Aside from its known general purposes of getting the right sets of people with acquired skills and knowledge to man strategic positions that will ease the flow of work, it is also of great importance to the survival of existing businesses and resuscitation of failed businesses. It is suggested that human resources management plays substantial role in the revitalization of failed entities therefore this paper $x$-rays its input in the entire processes.
\end{abstract}

Keywords - Moribund, Human Resource Management, Organisation, goals, Revitalization. 


\subsection{Introduction}

Aside the numerous roles of human resource management in work organizations which includes recruitment, selection, training, appraising performance, resourcing, planning, assessment and identification of key human resources needs of an organisation, there are still areas or roles that human resources management play generally in the business environment.

The unannounced roles go a long way in sustaining the growth and development of an enterprise and also remain a key factor in the revitalization of a failed or moribund venture.

In as much as human resources management is part of an entire organization's structure, there is lack of sufficient data to justify the involvement of human resources management in the process leading to the failure of an enterprise even though all units contribute to the failure process.

Looking at various reasons why businesses fail, it ranges from poor corporate governance as regards finance, lack of innovative ideas that could compete favorably, disloyal acts of employees' overtime and generally poor management. Scantily, human resource management is blamed for being part of the cause of the failure.

Many post-failure analysis have failed to put into consideration the critical role of human resource as a very strong tool in the revitalization process of the enterprise and this has in most cases returned the businesses back to the trenches. This paper x-rays the critical role human resource management plays in the revitalization of moribund enterprises.

\subsection{Conceptual Clarifications}

Human resources management plays a very key role in the entire management of the modern day organisation. This role also determines in most cases the sustainability of an enterprise.

Many scholars have defined human resources and human resources management in so many ways using so many terms.

Nzuve (1997) defined human resources as the workforce of an enterprise who plays one role or the other to ensure the daily running of the enterprise while also ensuring its success. This implies the totality of the people in the various departments of the organisation working round the clock to make it productive.

Storey (1995) cited in the works of Osibanjo and Adeniji (2012) on the theory and practice of human resources management sees human resources management as the strategic management of the human resources of an organisation towards gaining competitive advantage using committed employees. This involves the use of structural mechanisms and human resources management strategies in achieving results or desired outcomes.

There are dimensions to the roles and functions of human resources management as postulated by (Guest,1987) which includes the following.

Guest asserted that human resources management must identify key goals of an organisation and align suitable workforce that will believe in this goals with the organisation. He also made clarifications on the need for employees either new or existing to adapt to changes within the organisation as majority of changes in an organisation are geared towards the achievement of an organization's goal. 
Also, quality is expected to be the watchword of all serious organisation that strives to achieve excellence in the midst of growing business competition. Guest also concluded by opining that human resources strategy has to be matched by the needs of the business.

Aside the above postulations by Guest, human resources management plays some strategic key roles in an organisation. These key roles involves the following: developing highly skilled manpower for the future of the organisation, building commitments and loyalty amongst employees, arranging a team of talents to weather the storms and preparing adequately for competition.

\subsection{Moribund Enterprises}

Moribund can be described as a state of no function or a lifeless situation. In the business context, it could be described as the condition of a failed business. When an organisation is moribund, it means activities have been halted both in production and in administration and all units of the organization disengaged.

Enterprises go moribund in most cases as a result of stiff and unpleasant business atmosphere. It can also be attributed to the financial recklessness of the management. This happens when stringent financial regulations are not adhered to. Organizations can also go moribund due to global operating environment that could affect even the strongest of all businesses.

Outdated machineries that can no longer compete with modern technologies are also some of the reasons behind business failures. Imagine a situation where an airline flies an outdated aircraft as against its competitors flying modern planes. The business implication of this is that the airline will run out of business due to low patronage and safety concerns by potential clients and existing customers. Constant turnover of manpower can also lead to business failure and collapse. An organisation that fails to retain highly skilled and committed manpower will end up taking the back seat in the business world. Highly loyal and committed employees are key to business successes.

The sustainability of a business concern is in its ability to make profit and stand competition. Failure to achieve profitability is synonymous to business failure.

Several researchers have in many studies said the causes of business failure can be attributed to external factors as they are not predictable. He opined that the internal causes are usually known. Poor administrators in addition to the personality traits of the business owners can also lead to the moribund of a business (Berryman, 1983).

\subsection{Revitalization of Moribund Enterprise and the Role of Human Resources Management}

Moribund entities and freshly starting businesses can be likened to be the same. This is due to the fact that both are yet productive. The new business is still at the business plan stage while the moribund venture is still at the comatose stage.

Generally, human resources management coordinates the most of all plans in the floating of new ventures. This coordination includes recruitment, selection, training, motivation, job design, promotion policies and implementation of corporate strategies. Human resources management also ensures in new businesses that adequate manpower sufficient enough to run the enterprise are sourced. 
According to Cascio (1992), Human resource planning as a function of the human resources management ensures that strategic plans are in place to meet either the long term or short term plans of an organisation. This implies that it determines the quality and quantity of manpower that a firm needs and also allocates resources towards such. One of the human resources function of HRM is also to ensure the recruitment and selection of trustworthy and reliable hands to man the enterprise while also making sure they are placed in the right units. E.g. Square pegs in square holes.

Studies have shown that proper placement of employees brings out the best in the employees as it is one of the drivers of job satisfaction which in turn leads to commitments.

The human resources planning component of human resource management also ensures that the sufficient motivation is allocated to the various respective job descriptions. What is meant by sufficient motivation is the development of a very good reward system and promotional policy in the enterprise.

As part of the core functions and purpose of human resources management, it is also the responsibility of human resource management to develop a sustainable futuristic framework for training and development in the organisation.

Human resources managers and planners are also saddled with the responsibility of making sure they who ran the firm moribund does not find their ways back into the organisation especially those directly involved in the internal factors responsible for the failure of the business.

The human resources planning mandate of every organisation while trying to pick up from a moribund state must include long term strategies of managing the manpower of the organisation. This involves designing strong policies that will sustain the organisation long run.

The role of capacity building in either new or existing employees cannot be over-emphasized as this is the only strategy for improving the employee's knowledge about the job and how best to achieve organisational goals. Human capacity building is a core function of the human resource management and it keeps employees up to date in the ways things are done in contemporary times. It is an important strategy that an organization can utilize in the achievement of its long term goals (Laird, Holton III, \& Naquin, 2003). It has also been established that when employees are adequately trained, it makes it easier for an organization to achieve their set goals (Linderman, Schroeder, Zaheer, \& Choo, 2003).

Many business failures have also been attributed to the unethical human resource management policies exhibited by the owners of some of those moribund entities which allow them to just discretionarily employ people either competent or not based on family or societal ties. This which usually has led to unhealthy work behaviors and non-challant attitude on the side of the employees in question which are contributory factors internally that led to the firm's folding up. The onus lies on the human resource planners to ensure that when revitalizing a moribund entity, favoritism and family affiliations should be done away with in order to avoid repetitions of occurrences of the past.

For an organisation to get the commitment and loyalty of the employees, human resources management must make provisions for decision making participation of all employees in the entire organisational processes. This leads to a massage of ego and improves sense of belonging. When an employee feels among, he does everything possible to ensure the success 
and growth of the organisation. Studies of employee participation like that of Tata and Prasad (2004) have shown employees are committed to an organisation that welcomes opinion from employee and has a decentralized decision making process. This usually makes the employee to have the impression that their inputs led to the performance of the organisation. Employee participation should be one of the cardinal values of human resource planning both when floating a new entity or revitalizing a moribund firm.

Research has also shown that the failure of some companies especially those in the manufacturing sector stems from the inability of the organisation to attract the expertise to handle and maintain machineries overtime. This puts the firm in a situation whereby when machineries needs servicing, there won't be any hands to carry out the maintenance internally thereby leading to the abandoning of such machineries which are obviously the life wire of the company. Therefore human resources must be concerned about the sourcing of expatriates that will man working machineries and carry out repairs if need be.

The idea of creating a workable organisation structure is one of the core roles of human resources management due to the fact that organisational structure ensures the delegation of work and reporting lines of authority that defines the responsibility of all employees and organisation. If the previous strategies have failed, there is a need to develop a new structure that will be put to test at least on a temporary basis.

\subsection{Theoretical Underpinnings}

Motivation Theory: this theory believes that Motivation is a technique for instilling a strong desire to succeed. Individual needs are met in order to achieve organizational goals, and once this conditions are met, the better it is for the organisation. Administrators of organisations, according to Haque, Haque, and Islam (2014), are primarily responsible for ensuring that employees carry out their tasks or responsibilities correctly. To do so, the HRM must ensure that they have a skilled team of employees who can perform the jobs properly. Employees must be sufficiently inspired in order to maximize their efficiency.

\section{Conclusion}

Looking basically at the functions of human resource management in every organisation and its importance to the kick-starting and continuous stabilization of the business entity, we can as well say in its hands lie the life wires of the organisation.

Business organisations at the initial stage or moribund stage need the input of human resource managers in other to get the required manpower to man the organization. Without skilled and experienced manpower, an organisation cannot exist even when there are working tools on ground.

The revitalization process of every failed businesses comes with enormous challenges and requires meticulous inputs of all stakeholders in bringing it back to life. The various roles of the different stakeholders are of great value and importance. However, human resources management plays the front and leading role in the revitalization process as all hands needed in the entire re-floating processes are sourced and catered for by human resources management. Human resources management takes a critical look at the manpower failures of the failed organisation and address carefully gray areas that will assist in correcting some old wrongs.

Since the role of human resource planning as an HR function is to determine the future scope of an organisation while making plans towards aligning them with the attainment of 
African Journal of Business and Economic Development | ISSN: 2782-7658

Journal DOI: www.doi.org/10.46654/AJBED

Article DOI: www.doi.org/10.46654/AJBED.1559

organisational goals, it is in order to say human resources management plays an integral role in an organisation. 


\section{References}

Adeniji, A. A., \& Osibanjo, A. O. (2012). Human Resource Management: Theory \& Practice. Lagos, Nigeria: Pumark Nigeria Limited.

Berryman, J (1983). Small Business Failure and Bankruptcy: a Survey of the Literature. Eur. Small Bus. J., 1(4): 47-59

Cascio, W. F. (1992). Managing human resources: Productivity, quality of work life, profits. New York: McGraw-Hill. p.352

Guest, D. E. (1987). Human Resource Management and Industrial Relations, Journal of Management. Studies, 24(5):503-21. 32.

Haque, M. F., Haque, M. A., \& Islam, S., (2014). Motivational Theories - A Critical Analysis. ASA University Review, 8(1), 61- 68.

Laird, D., E.F. Holton, and S. Naquin. 2003. Approaches to Training and Development (Revised Ed.), Cambridge, MA: Perseus Books Group.

Linderman, K., R. G. Schroeder, S. Zaheer, and A. S. Choo. 2003. Six Sigma: A goal theoretic perspective. Journal of Operations Management 21, no. 2:193-203.

Nzuve, SNM; 1997; Management of human resources: A Kenyan perspective; ix, 178 p.

Storey, (1995): Human Resource Management, A Critical Text: London, New York: Routledge.

Tata, J., \& Prasad, S. (2004). Team self-management, organizational structure, and judgments of team effectiveness. Journal of Managerial Issues, 248-265. 